\title{
Wetland restoration and methanogenesis: the activity of microbial populations and competition for substrates at different temperatures
}

\author{
V. Jerman ${ }^{1,2}$, M. Metje ${ }^{1}$, I. Mandić-Mulec ${ }^{2}$, and P. Frenzel ${ }^{1}$ \\ ${ }^{1}$ Max-Planck-Institute for Terrestrial Microbiology, Karl-von-Frisch-Str., 35043 Marburg, Germany \\ ${ }^{2}$ University of Ljubljana, Biotechnical Faculty, Department of Food Science and Technology, Chair of Microbiology, \\ Večna pot 111, 1000 Ljubljana, Slovenia
}

Received: 29 December 2008 - Published in Biogeosciences Discuss.: 24 February 2009

Revised: 12 June 2009 - Accepted: 16 June 2009 - Published: 29 June 2009

\begin{abstract}
Ljubljana marsh in Slovenia is a 16000 ha area of partly drained fen, intended to be flooded to restore its ecological functions. The resultant water-logging may create anoxic conditions, eventually stimulating production and emission of methane, the most important greenhouse gas next to carbon dioxide. We examined the upper layer $(\sim 30 \mathrm{~cm})$ of Ljubljana marsh soil for microbial processes that would predominate in water-saturated conditions, focusing on the potential for iron reduction, carbon mineralization $\left(\mathrm{CO}_{2}\right.$ and $\mathrm{CH}_{4}$ production), and methane emission. Methane emission from water-saturated microcosms was near minimum detectable levels even after extended periods of flooding ( $>5$ months). Methane production in anoxic soil slurries started only after a lag period of $84 \mathrm{~d}$ at $15^{\circ} \mathrm{C}$ and a minimum of $7 \mathrm{~d}$ at $37^{\circ} \mathrm{C}$, the optimum temperature for methanogenesis. This lag was inversely related to iron reduction, which suggested that iron reduction out-competed methanogenesis for electron donors, such as $\mathrm{H}_{2}$ and acetate. Methane production was observed only in samples incubated at $14-38^{\circ} \mathrm{C}$. At the beginning of methanogenesis, acetoclastic methanogenesis dominated. In accordance with the preferred substrate, most (91\%) mcrA (encoding the methyl coenzyme-M reductase, a key gene in methanogenesis) clone sequences could be affiliated to the acetoclastic genus Methanosarcina. No methanogens were detected in the original soil. However, a diverse community of iron-reducing Geobacteraceae was found. Our results suggest that methane emission can remain transient and low if water-table fluctuations allow reoxidation of ferrous iron, sustaining iron reduction as the most important process in terminal carbon mineralization.
\end{abstract}

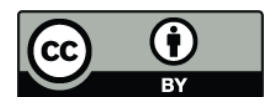

Correspondence to: P. Frenzel (frenzel@mpi-marburg.mpg.de)

\section{Introduction}

For centuries, most European wetlands have been drained and used for agricultural and industrial needs. It is estimated that more than half of all peatlands in Europe were lost because of human activities (Nivet and Frazier 2004). However, the attitude toward wetlands changed as their functions were understood better, and today conservation efforts abound. One of the most important functions worth saving is the ability of wetlands to store and clean water. Major restoration concepts along these lines include ceasing agriculture and re-establishment of wetland hydrology (Rosenthal 2003). Since wetlands are by definition permanently or temporarily flooded areas, raising the water table to original levels is thus the first step for a wetland revival.

Peatlands are characterised by soils rich in organic matter. Peat accumulated since the last glaciations corresponds to $20-30 \%$ of the global soil carbon pool (Frolking et al., 2001; Gorham, 1991). Drained peat decomposes rapidly (Andriesse, 1988). When submerged again, oxygen is exhausted quickly. Fermentation products such as acetate and $\mathrm{H}_{2}$ provide substrates for terminal oxidation processes. Reduction of terminal $\mathrm{e}^{-}$acceptors occurs sequentially according to thermodynamics: reduction of nitrate is followed by reduction of manganese, iron, sulphate, and finally by the reduction of $\mathrm{CO}_{2}$ or methyl groups to $\mathrm{CH}_{4}$ (Ponnamperuma, 1972). The water table, which affects oxygen availability and transport, is therefore an important determinant of gas emissions from peat soil (Aerts and Ludwig, 1997).

Iron is the fourth-most element in the earth's crust, and even in peatlands, iron reduction may shift the $\mathrm{e}^{-}$flow away from methanogenesis (Küsel et al., 2008). A wide variety of microbes can reduce iron oxides, but the Geobacteracea, members of the $\delta$-Proteobacteria subdivision, have most regularly been found associated with bacterial iron reduction.

Published by Copernicus Publications on behalf of the European Geosciences Union. 
Methane is next to $\mathrm{CO}_{2}$ the most important greenhouse gas (Intergovernmental Panel on Climate Change, 2007), and wetlands are the largest natural source of $\mathrm{CH}_{4}$, contributing approximately $20 \%$ of the global emissions (Matthews, 2000). While methane production is a strictly anaerobic process confined to anoxic layers, methane oxidation in freshwater wetlands depends on the presence of oxygen. Methane oxidation may control methane fluxes reducing potential emissions substantially (Conrad and Frenzel, 2002).

Methanogenesis itself depends on a sequence of microbial processes starting with hydrolysis of polymers, followed by primary and secondary fermentation, and ending with the methanogenic conversion of acetate and $\mathrm{H}_{2} / \mathrm{CO}_{2}$ (Conrad and Frenzel, 2002). The effect of temperature on methanogenesis and methanogenic pathways has been studied in different sediments and soils showing a wide variety of reactions: methanogenesis may dominate at low temperatures, while electrons are diverted to iron reduction at the respective temperature optimum of mineralization (Metje and Frenzel, 2005). $\mathrm{H}_{2} / \mathrm{CO}_{2}$ may be used preferably by acetogens at low temperature, but by methanogens at higher temperature (Schulz and Conrad, 1996). Finally, a thermophilic methanogenic sub-population may co-exist with mesophiles, taking over at elevated temperatures (Fey and Conrad, 2000).

Ljubljana marsh in central Slovenia is a large fen area that was reclaimed for agriculture. A drainage system was established already in the 19th century, however, Ljubljana marsh has never achieved the expected productivity. Today, agriculture is declining with grazing and haying being the most important usage. The biggest threat for conservation is currently the expansion of the neighbouring city and its infrastructures.

Conservation and restoration efforts have been initiated by BirdLive Slovenija. Since becoming part of the Natura 2000 network, there have been attempts to re-establish the natural properties. Because seasonal flooding is important e.g. for certain bird habitats, management plans include raising the water table. This will result in anoxic conditions in the flooded soils potentially leading to increased $\mathrm{CH}_{4}$ emissions. However, fluxes measured in the field showed only occasional minor $\mathrm{CH}_{4}$ emissions (Danevčič and J. Hacin, personal communication, 2006). Microcosm studies indicated that $\mathrm{CH}_{4}$ is produced only after a lag of two months, and only at elevated temperature (Stres et al., 2008).

In our study we focused on iron reduction and substrate availability as potential controls for $\mathrm{CH}_{4}$ production. In addition, the community structures of Archaea and Geobacteraceae was analyzed, taking the latter as representatives of mesophilic iron reducers. The experiment covered a wide temperature range giving a full picture of the physiological capabilities and limitations of the microbial community. In a second experiment, we used water-saturated soil in microcosms to study the interplay between methanogenesis and $\mathrm{CH}_{4}$ oxidation in a complex system. This work therefore provides fundamental information on the potential, extent, and distribution of different redox processes and associated microbial communities that could prevail after raising the water table level in the drained fen.

\section{Materials and methods}

\subsection{Site description and field sampling}

Ljubljana Marsh is a 16000 ha fen region located in central Slovenia $\left(45^{\circ} 58^{\prime} \mathrm{N}, 14^{\circ} 28^{\prime} \mathrm{E}\right)$. It is characterized by mineralrich ground water and neutral $\mathrm{pH}$. The average annual precipitation is $1400 \mathrm{~mm}$, and the mean annual temperature is $10^{\circ} \mathrm{C}$. A drainage-channel system was established in the 19th century and the landscape has been shaped ever since by peat extraction and agriculture. Today, $75 \%$ of the area is covered by grassland, $10 \%$ by forest, and $15 \%$ by cornfields. The experimental site is located on a grassland dominated by an Arrhenatherion (Seliškar, 1986). The water table is on average $50 \mathrm{~cm}$ below the surface, with pronounced seasonal fluctuations from flooded to $1 \mathrm{~m}$ below ground. The soil temperature in the upper $30 \mathrm{~cm}$ varies annually from $1^{\circ} \mathrm{C}$ to $20^{\circ} \mathrm{C}$.

Samples were collected at the end of August in 2005 with ten individual soil cores $(\mathrm{h}=30 \mathrm{~cm} ; \mathrm{d}=15 \mathrm{~cm})$ within a $10 \times 5 \mathrm{~m}^{2}$ area covering the upper $30 \mathrm{~cm}$ of soil. Soil samples were pooled, and plants and roots were removed to avoid litter input. The soil was homogenized by passing through a $3.15-\mathrm{mm}$ sieve. Immediately after homogenization, aliquots $(0.5 \mathrm{~g})$ for molecular analysis were frozen and stored at $-20^{\circ} \mathrm{C}$. The remainder was kept at $4^{\circ} \mathrm{C}$ for maximally two weeks until the experiments were set up. The pooled soil contained $32 \%$ organic matter, $78 \%$ water, and had a $\mathrm{pH}\left(\mathrm{H}_{2} \mathrm{O}\right)$ of 7.6. For a more detailed description of this soil see Hacin et al. (2001).

\subsection{Experimental design}

Net methane fluxes were measured from 25 microcosms $(\mathrm{d}=7 \mathrm{~cm} ; \mathrm{h}=10 \mathrm{~cm})$ filled with $250 \mathrm{~g}$ of homogenized soil and incubated for 65 days at $90 \%$ water holding capacity at $25^{\circ} \mathrm{C}$ in the dark. The water content was checked regularly by weighting the microcosms and adjusted with demineralised water, if necessary. $\mathrm{CH}_{4}$ and $\mathrm{CO}_{2}$ fluxes between soil and atmosphere were monitored monthly for 5 to $6 \mathrm{~h}$ after closing the headspace. $\mathrm{No} \mathrm{CH}_{4}$ emission was detectable after 65 days, and the microcosms were flooded and incubated for another 23 weeks at $25^{\circ} \mathrm{C}$. Gas fluxes were measured as before. Methane oxidation was measured comparing fluxes with and without difluoromethane $\left(\mathrm{CH}_{2} \mathrm{~F}_{2}\right)$, a specific inhibitor of $\mathrm{CH}_{4}$ oxidation (Miller and Oremland, 1998). Difluoromethane was added to a headspace concentration of $1 \%$ as described previously (Eller and Frenzel, 2001; Krüger et al., 2002).

Anaerobic processes were studied in anoxic soil slurries. Homogenized soil in 15 or $25 \mathrm{ml}$ pressure tubes was mixed with sterilized anoxic distilled water at a ratio of $1: 1.5$ 
(vol/vol) to a total volume of 6.5 (effect of temperature, see below) and $10 \mathrm{ml}$ (methanogenic pathways, see below). The tubes were closed with butyl rubber stoppers and flushed with $\mathrm{N}_{2}$. In inhibition experiments, $\mathrm{CH}_{3} \mathrm{~F}$, a specific inhibitor of acetoclastic methanogenesis, was added to the gas phase to a final concentration of $1 \%$ (Frenzel and Bosse 1996; Penning and Conrad 2006).

The effect of temperature was measured in 15-ml tubes incubated in a linear 0 to $80^{\circ} \mathrm{C}$ temperature gradient in the dark (Fey et al. 2001; Schulz et al. 1997). Tubes were incubated in duplicate at 30 temperatures for 115 days. $\mathrm{CO}_{2}$ and $\mathrm{CH}_{4}$ in the headspace were measured weekly, and $\mathrm{H}_{2}$ at the end of the experiment. At the end of the experiment, $0.5 \mathrm{ml}$ of each slurry was frozen at $-20^{\circ} \mathrm{C}$ for molecular analysis; the remainder was used for pore water, $\mathrm{Fe}(\mathrm{II})$, and $\mathrm{NH}_{4}^{+}$analysis.

The methanogenic pathways were analyzed in $25-\mathrm{ml}$ tubes at $25,30,37,47$, and $60^{\circ} \mathrm{C}$ for 68 days in the dark. Three replicates each with and without $\mathrm{CH}_{3} \mathrm{~F}$ were prepared. $\mathrm{CO}_{2}$, $\mathrm{CH}_{4}$, and $\mathrm{H}_{2}$ concentrations were measured weekly. Additional replicates were incubated at $25^{\circ} \mathrm{C}$. Every $1-2$ weeks, three of these replicates were sacrificed for pore water, Fe(II) and $\mathrm{NH}_{4}^{+}$analyses (see below).

\subsection{Analytical techniques}

Gas phase analysis. Gases were measured as described previously (Bodelier et al., 2000). In short, $\mathrm{CH}_{4}$ and $\mathrm{CO}_{2}$ concentrations were measured on a SRI-8160A GC (SRI Instruments, Torrance, $\mathrm{CA}$ ) with $\mathrm{H}_{2}$ as carrier gas equipped with a methanizer and a flame ionization detector. $\mathrm{H}_{2}$ concentrations were measured with a reducing gas detector (RGD2, Trace Analytical, Stanford, CA, USA). When $\mathrm{H}_{2}$ concentrations were $>200 \mathrm{ppm}_{v}$, a Shimadzu GC8A with $\mathrm{N}_{2}$ as carrier gas and a thermal conductivity detector was used. Before the headspace was sampled, the tubes were shaken to equilibrate headspace and pore-water. The volume of gas removed from each tube was replaced with the same volume of $\mathrm{N}_{2}$.

For pore water analysis, $2 \mathrm{ml}$ slurry was centrifuged (5 min at $12000 \times$ and $4^{\circ} \mathrm{C}$ ), and the supernatant was filtered through a $0.2-\mu \mathrm{m}$ filter. Organic acids and alcohols were measured by HPLC and GC, respectively, as described previously (Metje and Frenzel, 2005). Nitrate and sulphate were extracted from $0.15 \mathrm{~g}$ of wet soil or slurry by mixing with $600 \mu \mathrm{l}$ of distilled water for $1 \mathrm{~h}$. The extract was obtained as described above, and nitrate, nitrite and sulphate were determined by ion chromatography (Bak et al., 1991).

Reduced iron was extracted from $0.5 \mathrm{~g}$ of soil or $0.5 \mathrm{ml}$ of soil slurry with hydrochloric acid $(4.5 \mathrm{ml} ; 0.5 \mathrm{M})$ and measured spectrophotometrically (Lovley and Phillips, 1987b; Ratering and Schnell, 2000).

Exchangeable ammonium was extracted from $0.15 \mathrm{ml}$ soil slurry with $2 \mathrm{M} \mathrm{KCl}$ and determined fluorometrically using a microscale analysis (Goyal et al., 1988; Murase et al., 2006) on a SAFIRE micro-plate reader (TECAN, Crailsheim, Germany).

\subsection{Calculations}

Mineralization rates of soil organic matter were calculated from the measurements of $\mathrm{CO}_{2}$ and $\mathrm{CH}_{4}$ accumulation over time, using Origin Pro 6.1 (OriginLab Corp., USA). A single- or two- component exponential decay model was fitted using the equation:

$Y_{t}=C_{1} \cdot\left(1-e^{\left(-k_{1} \cdot\left(t-t_{0}\right)\right)}\right)$

for a single-component, and

$Y_{t}=C_{1} \cdot\left(1-e^{\left(-k_{1} \cdot\left(t-t_{0}\right)\right)}\right)+C_{2} \cdot\left(1-e^{\left(-k_{2} \cdot\left(t-t_{0}\right)\right)}\right)$

for a two-component exponential decay function (Murayama and Zahari, 1996a, b). $Y_{t}$ is the amount of $\mathrm{CO}_{2}$ or $\mathrm{CH}_{4}$ in the gas phase after time $t$ in days, $t_{0}$ is the length of the lag phase (for $\mathrm{CO}_{2}$ accumulation $t_{0}=0$ ), $C_{1}$ and $C_{2}$ are the initial pools, and $k_{1}$ and $k_{2}$ are rate constants for the mineralization of labile and recalcitrant organic fractions, respectively. Microbially not degradable fractions are not considered here. The half-life of a fraction was calculated from

$t_{1 / 2}=\ln (2) \cdot k^{-1}$

\subsection{Molecular methods}

Microbial community DNA was extracted from $0.5 \mathrm{~g}$ of the original soil sample, or from $0.5 \mathrm{~g}$ of soil slurry incubated in a temperature gradient block. DNA was purified using the Fast DNA SPIN Kit for Soil (Q-Biogene, Carlsbad, CA, USA). Humic acids were removed by additional washes with guanidine thiocyanate solution (5.5 M; Metje and Frenzel, 2005). The concentration of extracted DNA was determined spectrophotometrically on a BioPhotometer (Eppendorf, Hamburg, Germany) at $260 \mathrm{~nm}$. Enzymes and reagents for PCR reactions were obtained from Promega (Madison, WI, USA).

Archaeal 16S rRNA genes were amplified using primers A109f and A915r (Chin et al. 1999). For terminalrestriction fragment length polymorphism (T-RFLP) analysis, the reverse primer was labeled at the $5^{\prime}$ terminus with 5carboxyfluorescein, and PCR products were purified with the MinElute PCR Purification Kit (QiaGen, Düsseldorf, Germany). Approximately $50 \mathrm{ng}$ of DNA was digested with TaqI restriction endonuclease (Promega Corp., Madison, WI, USA) at $65^{\circ} \mathrm{C}$ for $3 \mathrm{~h}$. The procedures and equipment used for T-RFLP analysis were as described previously (Metje and Frenzel, 2005). The percentage abundance of each T-RF (A $p$ ) was calculated as $\mathrm{A} p=n \mathrm{i} \times 100 / N$ in which $n \mathrm{i}$ represents the peak height of one distinct T-RF and $N$ is the sum of all peak heights in a given T-RFLP profile.

The methanogenic communities were characterized by PCR amplification using three different $m c r A$-specific primer sets (Hales et al., 1996: ME1 and ME2; Luton et al., 2002: mcrAf and mcrAr; Springer et al., 1995: MCRf and MCRr). Only the primer set of Luton et al. (2002) yielded sufficient 
PCR product. Partial 16S rRNA gene sequences of the ironreducing Geobacteraceae were amplified with Geo564F and Geo840R primers (Cummings et al., 2003). For denaturing gradient gel electrophoresis (DGGE) analysis of Geobacteraceae, a GC clamp was added to the 5' end of the Geo840R primer. All PCR reactions followed protocols described by the respective authors. PCR products were cleaned with the MinElute PCR Purification Kit (QiaGen, Düsseldorf, Germany) and cloned into Escherichia coli JM109 competent cells via the pGEM-T Easy Vector System (Promega, Madison, WI, USA) according to the manufacturer's instructions. Selected clones were checked for correct insert size by vector-targeted PCR with vector-specific primers M13 and T7. Both strands of the correctly inserted DNA were sequenced using the ABI Prism Big Dye Terminator Cycle Ready Reaction Kit on an ABI 377 DNA sequencer (Applied Biosystems, Carlsbad, CA, USA) as specified by the manufacturer.

Geobacteraceae-targeting DGGE analysis was performed with a Bio-Rad system following the modified procedure of Cummings et al. (2003). The PCR product was loaded onto 1-mm thick 7.5\% (wt/vol) polyacrylamide gels containing a $30-60 \%$ linear denaturing gradient; $100 \%$ of denaturant was defined as $7 \mathrm{M}$ urea and $40 \%$ formamide. Electrophoresis was performed in $1 \mathrm{mM}$ TAE buffer at $60^{\circ} \mathrm{C}$ and a constant voltage of $65 \mathrm{~V}$ for $15 \mathrm{~h}$. After DGGE, gels were stained up to $1 \mathrm{~h}$ in $0.1 \%$ SYBR Green staining solution (Invitrogen, Carlsbad, CA, USA). Gels were scanned with a Typhoon Trio gel imager (GE Healthcare, UK). Gel images were linearized and analyzed with Photoshop CS2, version 9.02 (Adobe System Inc., San Jose, CA, USA). Bands were excised; each band was re-suspended in $20 \mu \mathrm{l}$ of elution buffer (QiaGen, Düsseldorf, Germany). DNA was amplified as described above, and the amplification products were verified by checking their position after DGGE. Forty-five distinct bands were excised again, and DNA was eluted, amplified, cleaned and sequenced. Out of 45 excised bands, 30 different sequences were obtained; 14 of the remaining sequences were identical to other sequences, and one was a chimera. Two clone mixtures of 10 defined clones were made to obtain additional markers for DGGE community profiles.

The sequences obtained were compared to sequences in the GenBank database using the Basic Local Alignment Search Tool (BLAST) to find highly similar sequences (megablast). Chimeric 16S rRNA gene sequences were identified by Chimera Check of Ribosomal Database Project II (release 8.1) (Cole et al., 2005). Sequences were aligned and phylogenetically analyzed with the ARB software package (Ludwig et al., 2004) using neighbour-joining and TreePuzzle (Schmidt et al., 2002). Details are given in the respective figure captions. All sequences have been deposited in the GenBank and EMBL databases. $m c r A$ sequences: EU753559-604; 16S rRNA-gene: EU753436-480 (Archaea), EU753481-510 (Geobacteraceae, excised bands) and EU753511-558 (Geobacteraceae, clones).
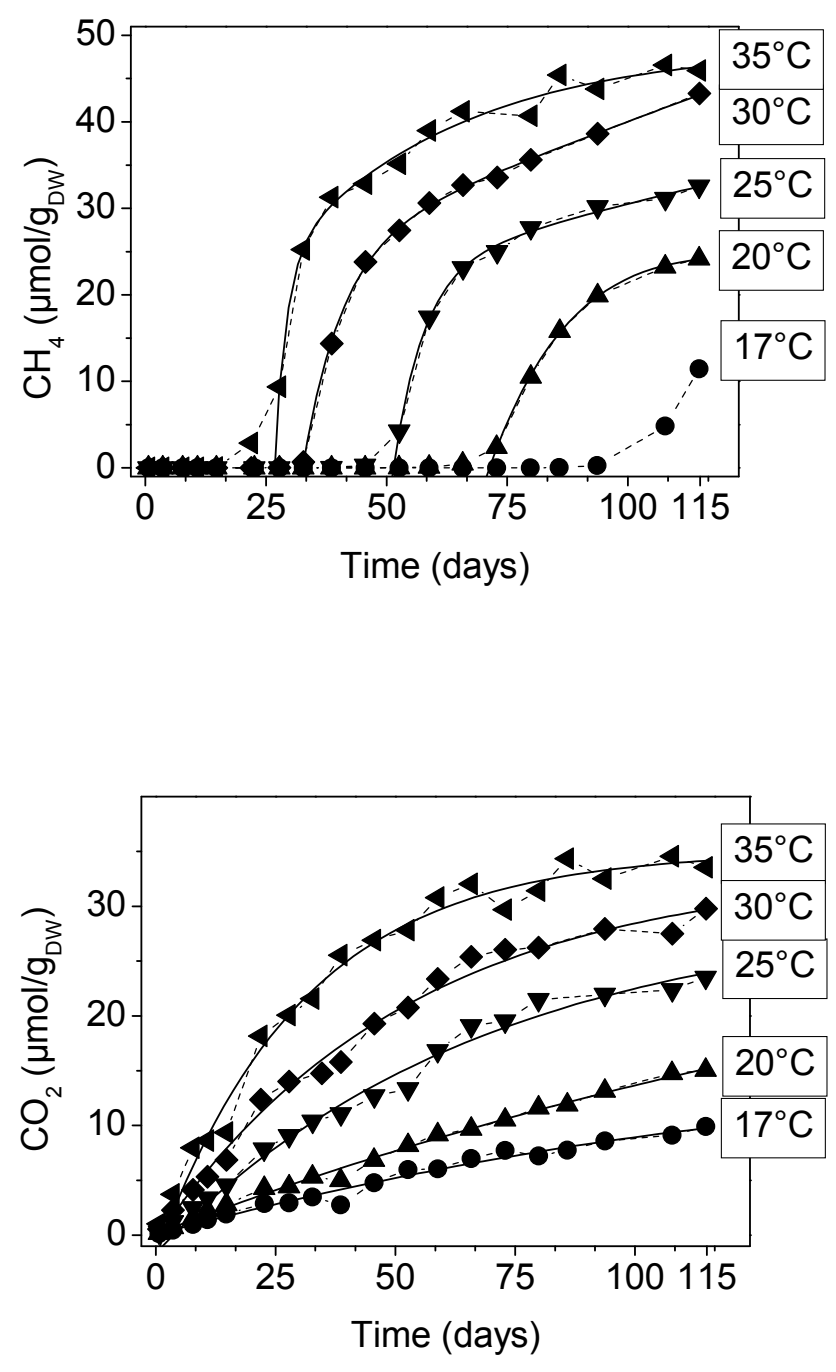

Fig. 1. Production of $\mathrm{CH}_{4}(\mathbf{A})$ and $\mathrm{CO}_{2}(\mathbf{B})$ over time in anoxic soil slurries at five temperatures. Solid lines were fitted by exponential decay models; for details see text.

\section{Results}

No $\mathrm{CH}_{4}$ was emitted from the flooded microcosms before 162 days of incubation. Methane emission was observed first in the presence of the $\mathrm{CH}_{4}$ oxidation inhibitor, $\mathrm{CH}_{2} \mathrm{~F}_{2}$, suggesting $\mathrm{CH}_{4}$ emissions were reduced by $\mathrm{CH}_{4}$ oxidation once production had started. Similarly, the soil slurries started producing $\mathrm{CH}_{4}$ only after a variable lag period, whereas $\mathrm{CO}_{2}$ concentrations increased immediately (Fig. 1).

The amount of $\mathrm{CO}_{2}$ in the gas phase of the soil slurries increased with time and with temperature (Figs. 1b, 2b). $\mathrm{CO}_{2}$ accumulation with time followed a single-component exponential decay model below $30^{\circ} \mathrm{C}$. Above $30^{\circ} \mathrm{C}$ a twocomponent exponential decay model gave a better fit. A two component model was also used to describe $\mathrm{CH}_{4}$ production. The rate constants of mineralization of the labile organic 

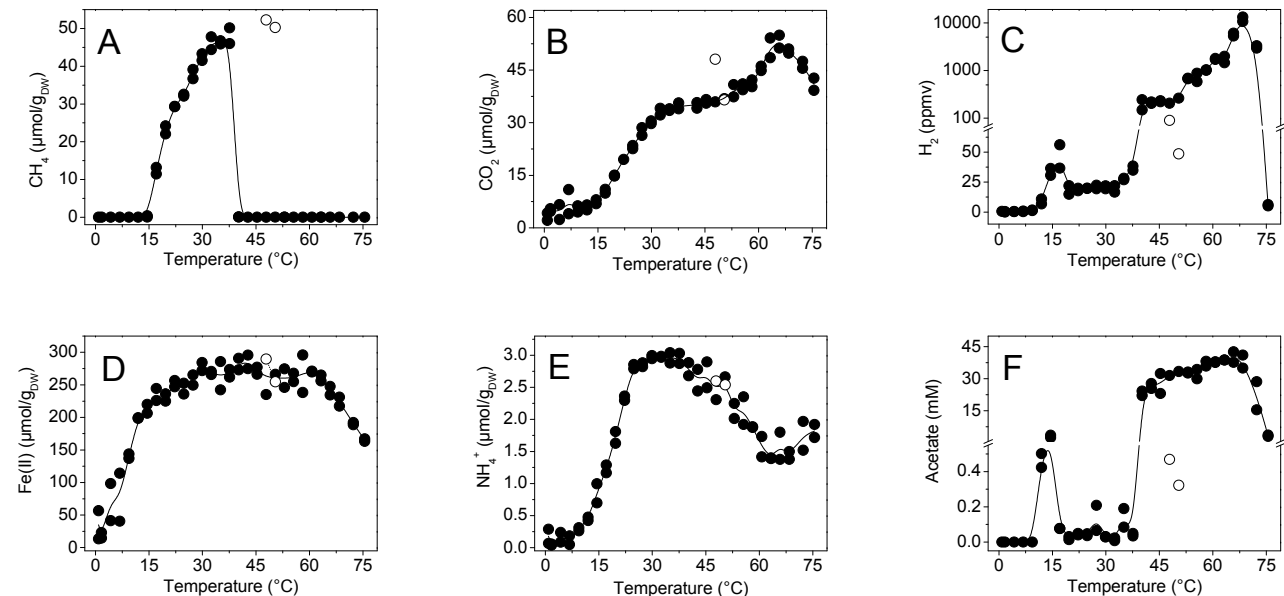

Fig. 2. Accumulation of $\mathrm{CH}_{4}(\mathbf{A}), \mathrm{CO}_{2}(\mathbf{B})$, and $\mathrm{H}_{2}$ (C) in the gas phase and concentrations of $\mathrm{Fe}(\mathrm{II})$ (D), $\mathrm{NH}_{4}^{+}$(E) and acetate (F) in pore water of anoxic soil slurries after incubation for 115 days. Open circles: see text for explanation. Solid lines connect the averages of the two replicates. Note the logarithmic scale in $\mathrm{C}$.

matter, obtained from $\mathrm{CO}_{2}$ accumulation values, increased with temperature from $0.01 \mathrm{~d}^{-1}\left(12^{\circ} \mathrm{C}\right)$ to $0.21 \mathrm{~d}^{-1}\left(72^{\circ} \mathrm{C}\right)$. However, rate constants of mineralization via methanogenesis varied from 0.04 to 0.17 independently of temperature. The half-lives of the labile organic matter calculated from $\mathrm{CO}_{2}$ accumulation decreased with increasing temperatures from 120 to 3 days, whereas mineralization through methanogenesis required 5-13 days, regardless of the temperature (Fig. 3a). The lag phase of methanogenesis corresponded to the half life of labile organic matter calculated from $\mathrm{CO}_{2}$ accumulation (Fig. 3b). We were unable to calculate precise mineralization rates of the refractory organic component at the given temperatures. Graphic analyses of refractory carbon mineralization suggested rate constants three orders of magnitude lower than for labile organic matter, with half-lives $>20 \mathrm{y}$.

Because of the non-linear increase of $\mathrm{CH}_{4}$ and $\mathrm{CO}_{2}$ (Fig. 1), the accumulation during the experiment is given instead of a rate per day in Fig. 2. Two temperature optima for $\mathrm{CO}_{2}$ accumulation were observed, one at $38^{\circ} \mathrm{C}$ and a second one at $65^{\circ} \mathrm{C}$ (Fig. 2b). Until the end of the experiment after 115 days, virtually no $\mathrm{CH}_{4}$ production was observed below $14^{\circ} \mathrm{C}$. The lag phase for methanogenesis decreased with increasing temperature from a maximum of 80 days at $15^{\circ} \mathrm{C}$, to a minimum of 7 days at the temperature optimum. Around $15^{\circ} \mathrm{C}$, elevated levels of $\mathrm{H}_{2}(50$ ppmv; Fig. 2c) and acetate $(500 \mu \mathrm{M}$; Fig. $2 \mathrm{f})$ coincided with a decreasing rate of $\mathrm{Fe}$ (II)-accumulation (Fig. 2d) and the onset of $\mathrm{CH}_{4}$ accumulation, suggesting a transitional phase between Fe-reduction and methanogenesis. The average steady-state concentrations in methanogenic samples were $26 \mathrm{ppm}_{v} \mathrm{H}_{2}$ and $60 \mu \mathrm{M}$ acetate $\left(15-38^{\circ} \mathrm{C}\right.$; Fig. $\left.2 \mathrm{c}, \mathrm{f}\right)$. The respective concentrations were much lower when Fe-reduction was prevalent at temperatures $<14^{\circ} \mathrm{C}$, with $2 \operatorname{ppm}_{v} \mathrm{H}_{2}$ and acetate below the de- tection limit. No other intermediate or substrate accumulated up to $40^{\circ} \mathrm{C}$. The temperature optimum for $\mathrm{CH}_{4}$ production was $38^{\circ} \mathrm{C}$, where $>40 \mu \mathrm{mol} \mathrm{g}$ dry $\mathrm{wt}^{-1} \mathrm{CH}_{4}$ accumulated after 115 days, with rates decreasing immediately when temperature increased (Fig. 2a). Ammonium concentrations were below the detection limit in the original soil. Above $10^{\circ} \mathrm{C}$, the concentration increased reaching an optimum at $32^{\circ} \mathrm{C}\left(3.04 \mu \mathrm{mol} \mathrm{NH}{ }_{4}^{+} \times \mathrm{g}\right.$ dry wt -1$)$.

Above $40^{\circ} \mathrm{C}$, very small amounts of $\mathrm{CH}_{4}$ accumulated from the beginning, but reaching not more than $33 \mathrm{nmol}$ $\mathrm{CH}_{4} \times \mathrm{g} \mathrm{dry} \mathrm{wt}^{-1}$ at the end of the experiment. However, two samples, incubated at $48^{\circ} \mathrm{C}$ and $50^{\circ} \mathrm{C}$ (Fig. 2, open circles), showed a different pattern: $\mathrm{CH}_{4}$ accumulated to high values, and alcohols, fatty acids, and $\mathrm{H}_{2}$ accumulated less. $\mathrm{H}_{2}$, fatty acids, and alcohols accumulated to high levels, with the highest concentrations at $66-76^{\circ} \mathrm{C}$.

A detailed analysis of the time course of iron reduction and methanogenesis was done at $25^{\circ} \mathrm{C}$. $\mathrm{Fe}$ (II) increased from the beginning till approximately 60 days (Fig. 4). The maximum concentrations of $\mathrm{Fe}(\mathrm{II})$ represented about $55-60 \%$ of the total iron content suggesting that roughly half of the chemically reducible iron was inaccessible for microbes. Methane production started while iron reduction began to decrease. At the onset of methanogenesis, hydrogenotrophic methanogensis contributed 30-75\% (Fig. 4). After 68 days, however, acetoclastic methanogenesis was prevalent at 25,30 , and $37^{\circ} \mathrm{C}$ $(95,60$, and $80 \%$, respectively).

To analyze the microbial community and its changes, archaeal and Geobacteraceae - related 16S rRNA genes, and the $m c r A$ gene were amplified, cloned, and analysed by $\mathrm{T}$ RFLP or DGGE. The amount of DNA extracted was highest in the original soil sample and decreased in soil slurries as the temperature increased. Above $60^{\circ} \mathrm{C}$, no PCR products could be obtained. The archaeal $16 \mathrm{~S}$ rRNA clone library of the 

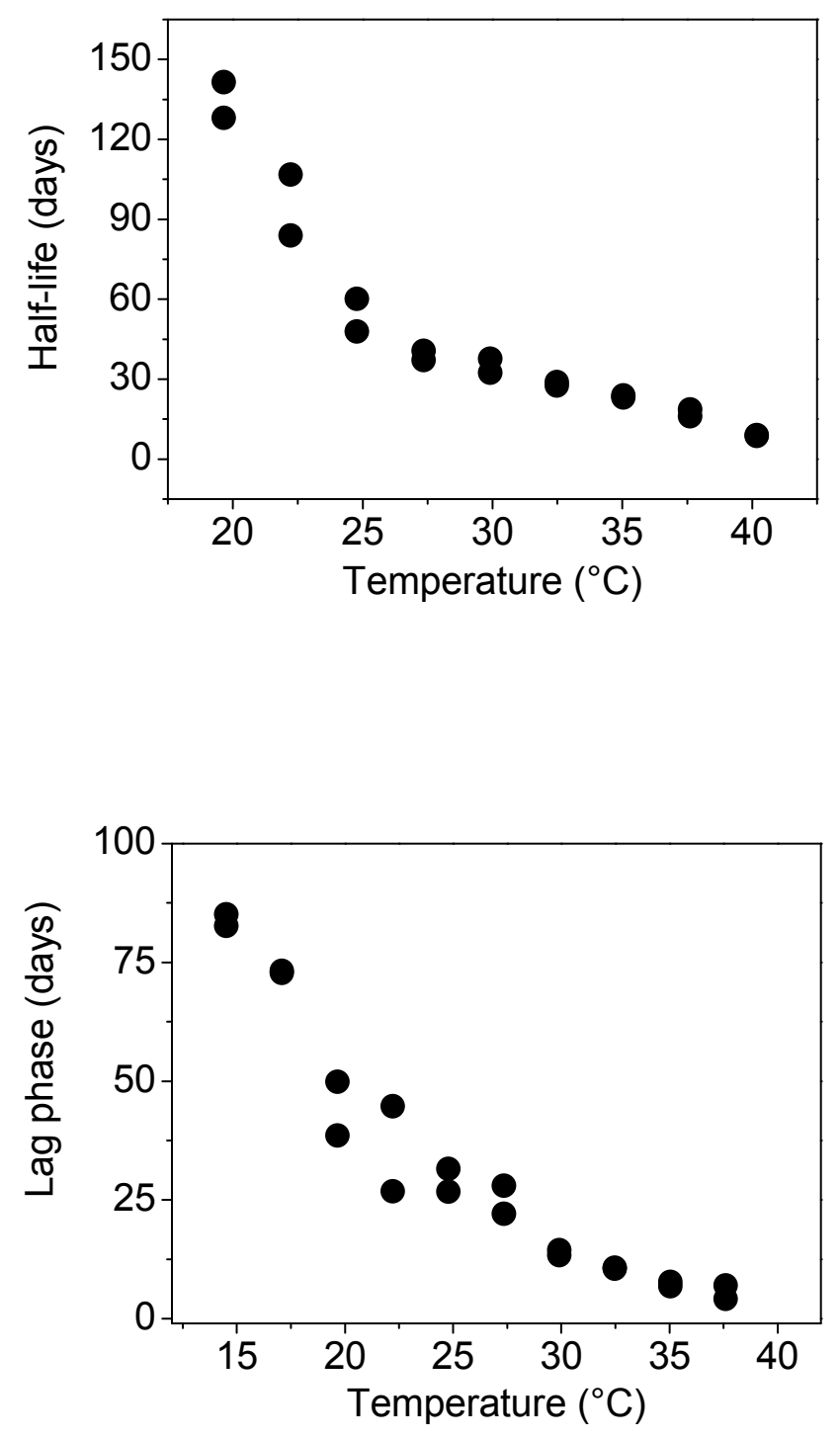

Fig. 3. (A) Half-life of labile soil organic matter calculated from $\mathrm{CO}_{2}$ production in anoxic soil slurries incubated at different temperatures. (B) Lag phase for $\mathrm{CH}_{4}$ production in anoxic soil slurries incubated at different temperatures.

original soil consisted exclusively of crenarchaeal sequences with no methanogenic representatives (45 of 46 clone sequences; one was a chimera). All sequences belonged to the yet uncultured rice cluster VI (RC-VI) of Crenarchaeota (Fig. 5) (Chin et al., 1999; Kemnitz et al., 2004).

T-RFLP analysis of archaeal 16S rRNA genes from samples incubated at various temperatures yielded four distinct T-RFs of $185,382,394$, and 735 . The original soil yielded only two T-RFs of 140 and $185 \mathrm{bp}$. The dominating fragment (185 bp; Ap 46-100\%) was present in all samples. TRFs of 382 , 394, and $735 \mathrm{bp}$ were found in samples incubated at $20-38^{\circ} \mathrm{C}$. The $382-$ and 394-bp T-RFs increased at higher temperatures $\left(30-38^{\circ} \mathrm{C}\right)$, with an A $p$ up to 6 and $30 \%$,

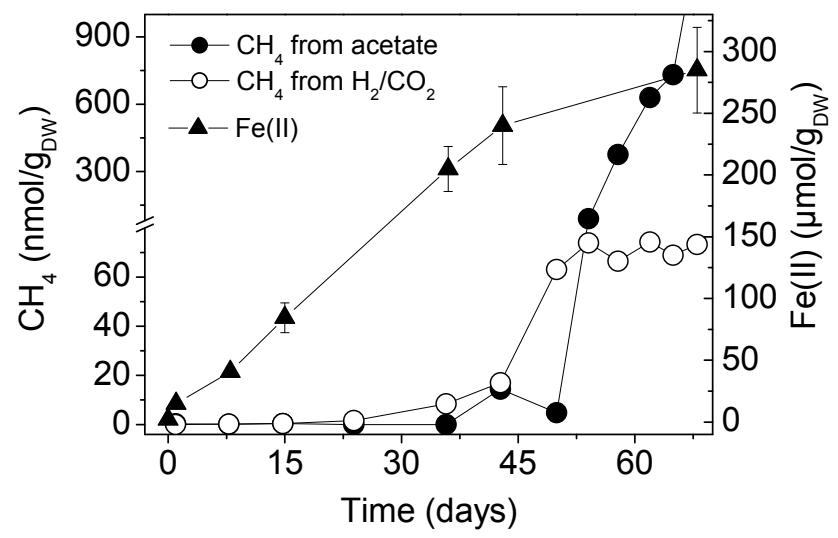

Fig. 4. Methanogenic pathways and iron reduction at $25^{\circ} \mathrm{C}$. The values of $\mathrm{CH}_{4}$ produced from either $\mathrm{H}_{2} / \mathrm{CO}_{2}$ or acetate were calculated from averages $(n=2-3)$ of $\mathrm{CH}_{4}$ concentrations measured in the presence (methanogenesis from $\mathrm{H}_{2} / \mathrm{CO}_{2}$ only) and in the absence of methyl fluoride. $\mathrm{Fe}(\mathrm{II})$ : average $\pm \mathrm{SE}, n=6$.

respectively. It is suggested that the T-RFs of $185 \mathrm{bp}$ represents members of Methanosarcinaceae or RC-VI (Kemnitz et al. 2004), $382 \mathrm{bp}$ members of the euryarchaeal RC-III, and the T-RF of $394 \mathrm{bp}$ members of the methanogenic RC-I, (Kemnitz et al., 2004; Lu et al., 2005; Penning and Conrad, 2006). This affiliation is consistent with the clone library: archaeal 16S rRNA gene clone sequences from the original soil belonged exclusively to RC-VI (Fig. 5), and mcrA clone sequences from a methanogenic slurry incubated at $35^{\circ} \mathrm{C}$ were represented by acetoclastic Methanosarcina and hydrogenotrophic RC-I at a ratio of 91:9 (Fig. 6).

Geobacteraceae-targeting PCR yielded a strong product for all samples incubated below $40^{\circ} \mathrm{C}$. There was no obvious difference in DGGE bands between samples incubated at 1$27^{\circ} \mathrm{C}$ (Fig. 7). In samples incubated at $30-35^{\circ} \mathrm{C}$, the community shifted and stabilized again at $38^{\circ} \mathrm{C}$. Banding patterns remained constant up to $60^{\circ} \mathrm{C}$, at which the bands became fainter, suggesting lower target numbers. The Geobacteraceae 16S rRNA gene clone library from the original soil contained 48 different clones. DGGE-bands were excised, re-amplified and sequenced.

All sequences $(n=74)$ clustered within the order Desulfuromonadales, including the the $\mathrm{Fe}(\mathrm{III})$ reducing genera Geobacter, Desulfuromonas and Pelobacter. One sequence was affiliated to the genus Anaeromyxobacter. The clones and the respective DGGE bands were assigned to groups IXI (Fig. 8). The vast majority of bands were positioned on the gradient gel between 40 and 55\% denaturant. The bands positioned at denaturant concentrations $>55 \%$ (not shown) belonged to the iron reducer Anaeromyxobacter. Most bands were present throughout the whole temperature range but differing in relative intensity. 


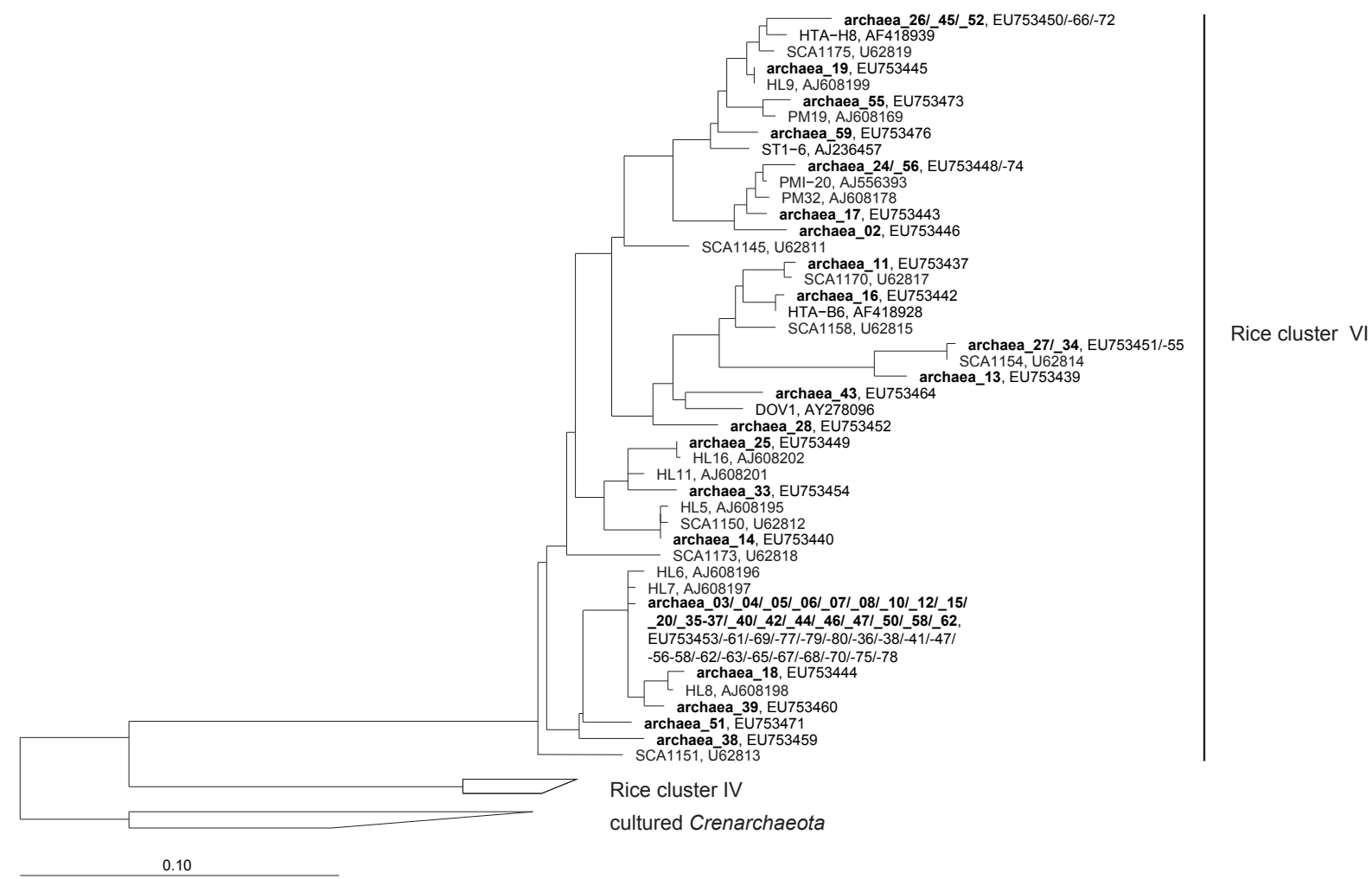

Fig. 5. Crenarchaeota, rice cluster VI: neighbour-joining tree of $16 \mathrm{~S}$ rRNA gene sequences. Clones retrieved from the original soil (bold), from upland (Bintrim et al., 1997) and flooded soils (Kemnitz et al., 2004). GenBank accession numbers of the sequences are indicated. Scale bar: estimated number of base changes per nucleotide position.

\section{Discussion}

If methanogenesis had occurred regularly in this soil, it would have recovered quickly after flooding had caused anoxic conditions. However, $\mathrm{CH}_{4}$ production began only after a long lag phase. This implies that either methanogenesis was inhibited by another process, and/or methanogen abundance was low. Denitrification and sulphate reduction could be ruled out as competing processes, because the respective electron acceptors were virtually absent. Fe(III), in contrast, proved to be a major electron sink. The length and course of iron reduction coincided well with the lag phase for $\mathrm{CH}_{4}$ production. Iron reduction started immediately after the start of incubation and production of $\mathrm{CH}_{4}$ was completely suppressed until $\sim 2 / 3$ of iron was reduced.

Iron reducers have a higher affinity for $\mathrm{H}_{2}$ and acetate than methanogenic archaea, and they can grow at lower $\mathrm{H}_{2}$ and acetate concentrations (Lovley and Phillips, 1986; Lovley and Phillips, 1987a). Fe-reducing bacteria form a polyphyletic functional group. While a PCR-assay directed against a functional gene common to all Fe-reducing bacteria is not available, the PCR-assay targeting the 16S rRNA gene covers a significant fraction of these organisms (Cummings et al., 2003). Geobacteraceae can use short-chain fatty acids, monoaromatic compounds, and hydrogen as electron donors (Lovley, 2000). Most of the DGGE-bands in samples incubated above $30^{\circ} \mathrm{C}$ could be affiliated with iron reducers that can use very diverse electron donors (Geobacter pelophilus, Pelobacter acetylenicus, and Pelobacter propionicus; Fig. 7). At lower temperatures, one of the pronounced bands belonged to group XI that could be affiliated to the acetate oxidizing Desulfuromonas acetoxidans. Competition for acetate is suggested by the very low acetate concentration in the Fereducing samples (Fig. 2d, f). Methanosaeta is reported to have an acetate threshold of $20 \mu \mathrm{M}$, with $200-500 \mu \mathrm{M}$ being claimed to be necessary for Methanosarcina (Jetten et al., 1990). Since Methanosaeta was not detected, the acetate concentration measured at temperatures $<14^{\circ} \mathrm{C}$ is well in accordance with competition with iron reducers for acetate, while a direct temperature control of methanogenic populations was not evident. $\mathrm{H}_{2}$ concentration in these samples was $\leq 1 \mathrm{nM}$, but may have allowed minor $\mathrm{CH}_{4}$ formation (Fig. $2 \mathrm{c}$, 4) (Karadagli and Rittmann, 2007). This agrees with observations in a rice field and in rice soil microcosms, in which only minor residual $\mathrm{CH}_{4}$ production from $\mathrm{H}_{2} / \mathrm{CO}_{2}$ occurred during the Fe-reducing phase (Frenzel et al., 1999; Krüger et al., 2002; Lueders and Friedrich, 2002). The higher levels of $\mathrm{H}_{2}$ and acetate in $15^{\circ} \mathrm{C}$-samples coincided with the onset 


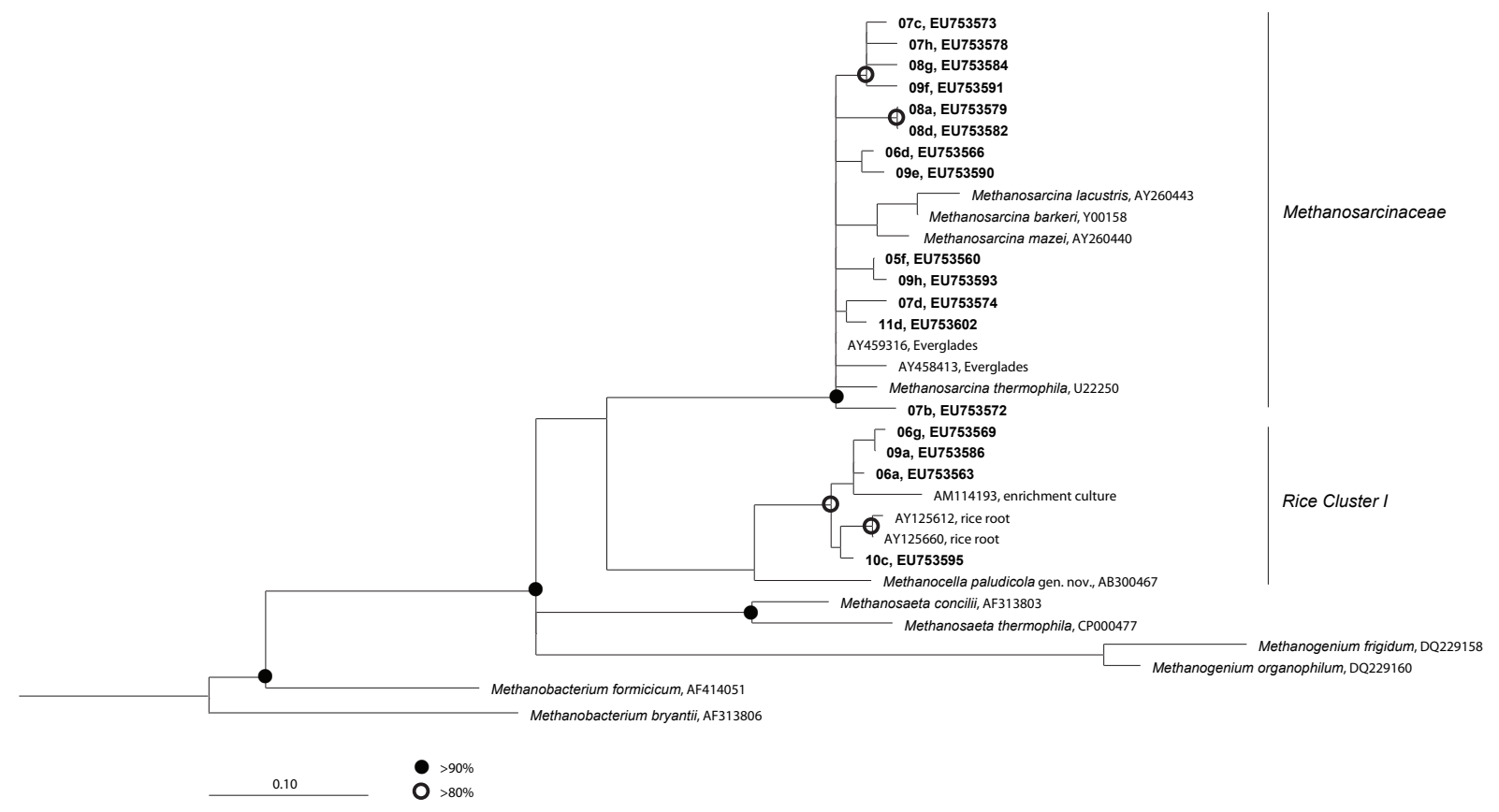

Fig. 6. Methanogenic Archaea: Tree-Puzzle tree of $m c r A$-sequences. The tree was calculated with 10000 puzzling steps, the WhelanGoldman substitution model, parameter estimation using neighbor-joining, a filter 20-100\%, and 160 valid columns. Sequences retrieved after incubation at $35^{\circ} \mathrm{C}$ for 115 days are printed in bold. Scale bar: estimated number of changes per amino acid position. Root: Methanopyrus kandleri (AF414042). Clone sequences were aligned against an ARB-database with 2500 mcrA sequences. Nearest cultivated and environmental neighbors were identified after adding the clone sequences with the quick add tool (parsimony) to an existing working tree with $\sim 2500$ sequences. Since clone sequences were forming coherent clusters, only 17 representatives out of 45 sequences were subsequently used together with the nearest cultivated and environmental sequences to generate the initial maximum-likelihood tree.

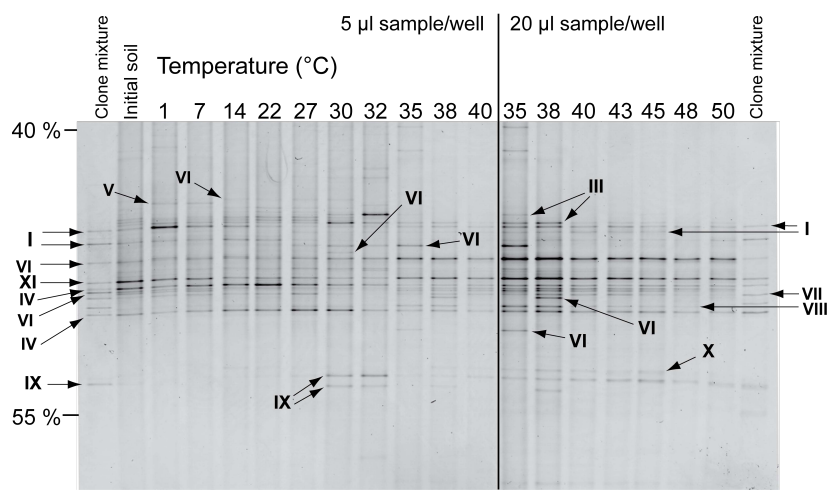

Fig. 7. Geobacteraceae and related Desulfuromonadales: DGGEprofiles of 16S rRNA gene fragments from the original soil and after incubation at different temperatures. Individual bands that yielded sequence data are labelled with group numbers (Roman numerals). The denaturant gradient is indicated to the left in $\%$.

methanogenesis (Fig. 2). Considering that prior to incubation no methanogens could be detected, these data indicate that fermentation and methanogenesis had not yet reached a steady state.
The archaeal 16S rDNA gene sequences retrieved from the original soil fell all into rice cluster VI, a group of nonmethanogenic Crenarchaeota. Rice cluster VI has been found in various freshwater and terrestrial habitats, but its physiology is still unknown (Kemnitz et al., 2004; Ochsenreiter et al., 2003). These data support the assumption that methanogenesis in the upper $30 \mathrm{~cm}$ of Ljubljana marsh soil is not a process that occurs naturally, even after longer periods of flooding. Our results indicate that rare representatives of a methanogenic community were present and became enriched during incubation, at least at temperatures above $15^{\circ} \mathrm{C}$. Indeed, methanogens have been shown to survive prolonged oxic conditions (Mayer and Conrad, 1990; Peters and Conrad, 1995). Hence, re-establishing a methanogenic community is to be expected after flooding, but it will have to cope with the competition for electron donors by Fe-reducing bacteria.

The Methanosarcinaceae detected in samples with high $\mathrm{CH}_{4}$ production are able to use acetate corresponding well to the high fraction of acetoclastic methanogenesis. The acetate concentrations of $60 \mu \mathrm{M}$ in the methanogenic samples, however, were still lower than thresholds reported for pure cultures (Jetten et al., 1990), but as high as observed in a methanogenic rice field soil (Leybo et al., 2006). A minor 


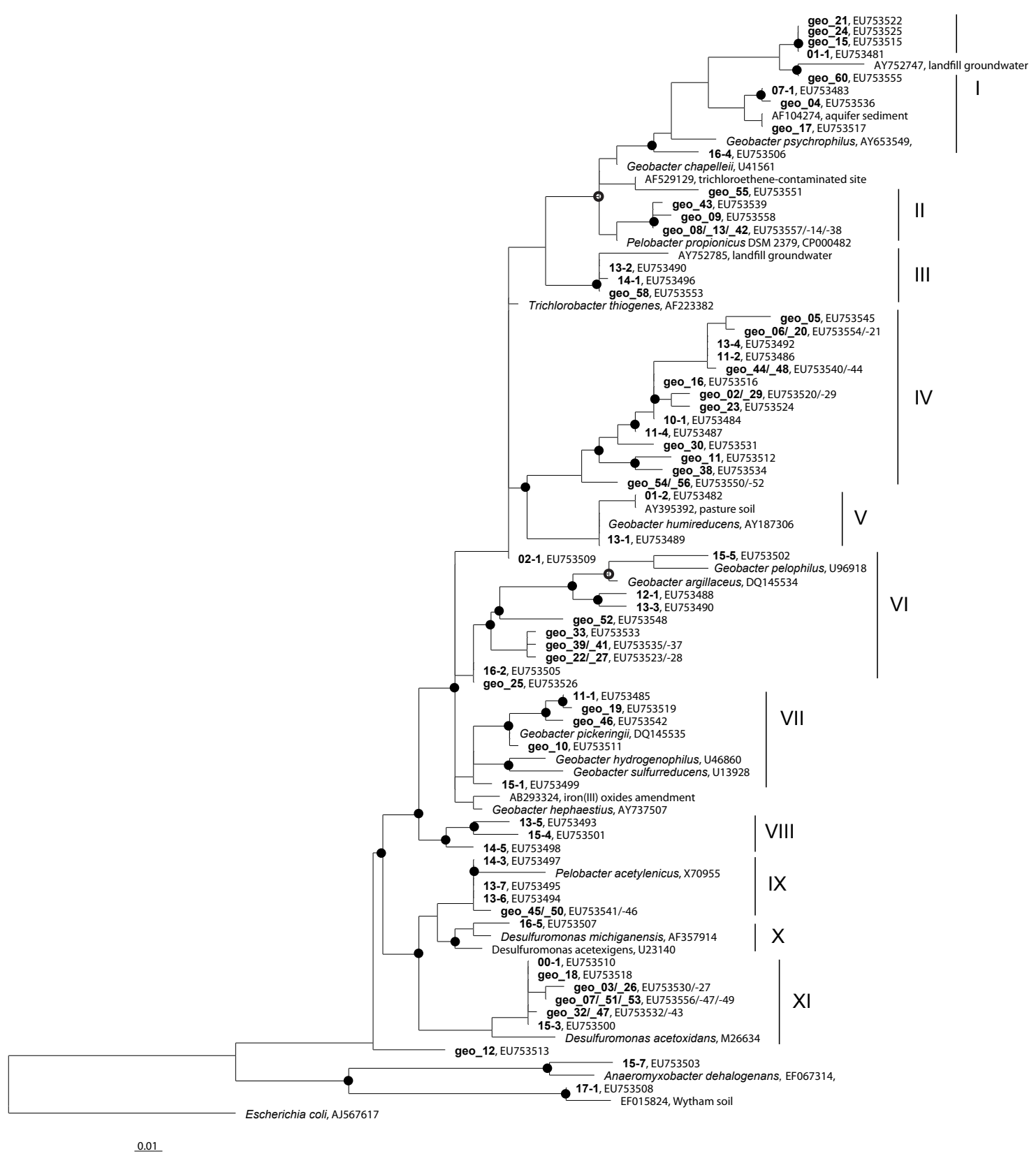

Fig. 8. Geobacteraceae and related Desulfuromonadales: neighbour-joining tree of $16 \mathrm{~S}$ rRNA gene sequences retrieved from the original soil, or recovered from DGGE bands (Fig. 7). First a stable bootstrap tree with sequences from cultured and uncultured species with $>1300$ bases was constructed. Afterwards clone sequences and sequences from DGGE (in bold) were added by quick add (parsimony) as implemented in ARB, considering a total of 313 base positions. Closed symbols: $\geq 90 \%$; open symbols: $\geq 80 \%$; scale bar: estimated number of base changes per nucleotide position. As root Escherichia coli (AJ567617) was used.

fraction of methanogenic archaea in our samples were affiliated with RC-I. Members of RC-I are hydrogenotrophic and more active at low $\mathrm{H}_{2}$ concentrations ( $\mathrm{Lu}$ and Conrad, 2005), which allows them to grow in syntrophy with secondary fermenters (Lueders et al., 2004). RC-I is often found in periodically oxic environments, suggesting that they are well adapted to oxic stress during periods of drought (Con- rad et al., 2006). Recently, this was supported by a complete genome analysis of RC-I (Erkel et al., 2006), predicting the presence of a complex set of enzymes and mechanisms protecting this organism against oxidative stress.

Soil organic matter is a complex mixture of different components. In short-term experiments, $\mathrm{CO}_{2}$ and $\mathrm{CH}_{4}$, the end-products of carbon mineralization, often increase 
linearly with time. For this long-term experiment, lasting 115 days, two-component decay models describing the different degradability of a labile and a refractive fraction gave a better fit (Murayama and Zahari, 1996b). The labile fraction had a half-life of about 130 days at $20^{\circ} \mathrm{C}$, the in situ summer temperature in the soil layer studied. The shorter half-life calculated for methanogenesis was lacking an obvious temperature response suggesting that production of methanogenic precursors and overall mineralization were only loosely coupled. The temperature optimum for methanogens was relatively high compared to northern wetlands (Metje and Frenzel, 2005; Metje and Frenzel, 2007), but comparable to that found for methanogenesis in an Italian rice field soil (Fey et al., 2001). This suggests a common adaptation to the climate in the Mediterranean, and a latitudinal differentiation of microbial populations in flooded soils. Furthermore, the outliers in $\mathrm{CH}_{4}$ accumulation at $48-50^{\circ} \mathrm{C}$ (Fig. 2a) indicate the presence of a cryptic moderately thermophilic population like that found in an Italian rice field soil (Fey et al., 2001). However, the adaptive value of such a trait is entirely unclear.

We have shown that re-establishment of a methanogenic population and, hence, production of $\mathrm{CH}_{4}$ was limited by competition for substrates, mainly for acetate. In the presence of Fe(III), methanogenesis will be largely delayed over a wide temperature range. The long-term effects after restoring a high water-table are more difficult to predict: timing of methanogenesis does not only depend on competing terminal processes, but also on labile organic carbon. Its availability will depend on plant exudates and litter input that were not part of our study. However, if the water-table is allowed to fluctuate, the iron oxidation-reduction cycle is expected to continue, as corroborated by other studies (Küsel et al., 2008). Hence, intermittent drainage events, preferably during the warm season, may be the most promising strategy mitigating $\mathrm{CH}_{4}$ emissions. In addition, the microcosmexperiment has shown that $\mathrm{CH}_{4}$ may be oxidized by methanotrophs before it can escape into the atmosphere. Overall, our results suggest that restoration strategies proposed for Ljubljana marsh will not necessarily increase $\mathrm{CH}_{4}$ emission.

Acknowledgements. This work was supported by the Max-PlanckSociety, by the Slovenian Research Agency grant J4-6149-0481-04, Centre of Excellence Environmental Technology Grant awarded to IM-M, Slovenian Research Agency grant P4-0116, and by the Ad Futura Scholarship Fund of the Republic of Slovenia awarded to V.J.

Edited by: K. Küsel

\section{References}

Aerts, R. and Ludwig, F.: Water-table changes and nutritional status affect trace gas emissions from laboratory columns of peatland soils, Soil Biol. Biochem., 29, 1691-1698, 1997.

Andriesse, J. P.: Nature and Management of Tropical Peat Soils, FAO Soils Bulletin, 59, 1-178, ISBN: 92-5-102657-2, 1988.
Bak, F., Scheff, G., and Jansen, K. H.: A rapid and sensitive ion chromatographic technique for the determination of sulfate and sulfate reduction rates in freshwater lake sediments, FEMS Microbiol. Ecol., 85, 23-30, 1991.

Bodelier, P. L. E., Hahn, A., Arth, I., and Frenzel, P.: Effects of ammonium-based fertilisation on microbial processes involved in methane emission from soils planted with rice, Biogeochemistry, 51, 225-257, 2000.

Bintrim, S. B., Donohue, T. J., Handelsman, J., Roberts, G. P., and Goodman, R. M.: Molecular phylogeny of Archaea from soil, PNAS, 94, 277-282, 1997.

Chin, K. J., Lukow, T., and Conrad, R.: Effect of temperature on structure and function of the methanogenic archaeal community in an anoxic rice field soil, Appl. Environ. Microbiol., 65, 23412349, 1999.

Cole, J. R., Chai, B., Farris, R. J., Wang, Q., Kulam, S. A., McGarrell, D. M., Garrity, G. M., and Tiedje, J. M.: The Ribosomal Database Project (RDP-II): sequences and tools for highthroughput rRNA analysis, Nucl. Acid. Res., 33, D294-D296, 2005.

Conrad, R., Erkel, C., and Liesack, W.: Rice Cluster I methanogens, an important group of Archaea producing greenhouse gas in soil, Curr. Opinion Biotech., 17, 262-267, 2006.

Conrad, R. and Frenzel, P.: Flooded soils, in: Encyclopedia of Environmental Microbiology, edited by: Britton, G., John Wiley \& Sons, New York, USA, 1316-1333, 2002.

Cummings, D. E., Snoeyenbos-West, O. L., Newby, D. T., Niggemyer, A. M., Lovley, D. R., Achenbach, L. A., and Rosenzweig, R. F.: Diversity of Geobacteraceae species inhabiting metalpolluted freshwater lake sediments ascertained by $16 \mathrm{~S}$ rDNA analyses, Microb. Ecol., 46, 257-269, 2003.

Eller, G. and Frenzel, P.: Changes in activity and community structure of methane oxidising bacteria over the growth period of rice, Appl. Environ. Microbiol., 67, 2395-2403, 2001.

Erkel, C., Kube, M., Reinhardt, R., and Liesack, W.: Genome of Rice Cluster I archaea - the key methane producers in the rice rhizosphere, Science, 313, 370-372, 2006.

Fey, A., Chin, K. J., and Conrad, R.: Thermophilic methanogens in rice field soil, Environ. Microbiol., 3, 295-303, 2001.

Fey, A. and Conrad, R.: Effect of temperature on carbon and electron flow and on the archaeal community in methanogenic rice field soil, Appl. Environ. Microbiol., 66, 4790-4797, 2000.

Frenzel, P. and Bosse, U.: Methyl fluoride, an inhibitor of methane oxidation and methane production, FEMS Microbiol. Ecol., 21, 25-36, 1996.

Frenzel, P., Bosse, U., and Janssen, P. H.: Rice roots and methanogenesis in a paddy soil: ferric iron as an alternative electron acceptor in the rooted soil, Soil Biol. Biochem., 31, 421-430, 1999.

Frolking, S., Roulet, N. T., Moore, T. R., Richard, P. J. H., Lavoie, M., and Muller, S. D.: Modeling northern peatland decomposition and peat accumulation, Ecosystems 4, 479-498, 2001.

Gorham, E.: Northern peatlands - role in the carbon cycle and probable responses to climatic warming, Ecol. Appl. 1, 182-195, 1991.

Goyal, S. S., Rains, D. W., and Huffaker, R. C.: Determination of ammonium ion by fluorometry or spectrophotometry after online derivatization with ortho-phthalaldehyde, Anal. Chem., 60, 175179, 1988.

Hacin, J., Cop, J., and Mahne, I.: Nitrogen mineralization in marsh 
meadows in relation to soil organic matter content and watertable level, J. Plant Nutr. Soil Sci., 164, 503-509, 2001.

Hales, B. A., Edwards, C., Ritchie, D. A., Hall, G., Pickup, R. W., and Saunders, J. R.: Isolation and identification of methanogenspecific DNA from blanket bog feat by PCR amplification and sequence analysis, Appl. Environ. Microbiol., 62, 668-675, 1996.

Intergovernmental Panel on Climate Change: Climate Change 2007: The Physical Science Basis. Summary for Policymakers. Contribution of Working Group I to the Fourth Assessment Report of the Intergovernmental Panel on Climate Change, 2007.

Jetten, M. S. M., Stams, A. J. M., and Zehnder, A. J. B.: Acetate threshold values and acetate activating enzymes in methanogenic bacteria, FEMS Microbiol. Ecol., 73, 339-=-344, 1990.

Karadagli, F. and Rittmann, B.: Thermodynamic and kinetic analysis of the $\mathrm{H}_{2}$ threshold for Methanobacterium bryantii M.o.H, Biodegradation, 18, 439-452, 2007.

Kemnitz, D., Chin, K. J., Bodelier, P., and Conrad, R.: Community analysis of methanogenic archaea within a riparian flooding gradient, Environ. Microbiol., 6, 449-461, 2004.

Krüger, M., Eller, G., Conrad, R., and Frenzel, P.: Seasonal variation in pathways of $\mathrm{CH}_{4}$ production and in $\mathrm{CH}_{4}$ oxidation in rice fields determined by stable carbon isotopes and specific inhibitors, Global Change Biol., 8, 265-280, 2002.

Küsel, K., Blöthe, M., Schulz, D., Reiche, M., and Drake, H. L.: Microbial reduction of iron and porewater biogeochemistry in acidic peatlands, Biogeosciences, 5, 1537-1549, 2008, http://www.biogeosciences.net/5/1537/2008/.

Leybo, A. I., Netrusov, A. I., and Conrad, R.: Effect of hydrogen concentration on the community strycture of hydrogenotrophic methanogens studied by T-RELP analysis of 16S rRNA gene amplicons, Microbiology, 75, 683-688, 2006.

Lovley, D. R.: $\mathrm{Fe}(\mathrm{III})$ and $\mathrm{Mn}(\mathrm{IV})$ reduction, in: Environmental Microbe-Metal Interactions, edited by: Lovley, D. R., ASM Press, Washington DC, USA, 3-24, 2000.

Lovley, D. R. and Phillips, E. J. P.: Organic matter mineralization with reduction of ferric iron in anaerobic sediments, Appl. Environ. Microbiol., 51, 683-689, 1986.

Lovley, D. R. and Phillips, E. J. P.: Competitive mechanisms for inhibition of sulfate reduction and methane production in the zone of ferric iron reduction sediments, Appl. Environ. Microbiol., 53, 2636-2641, 1987a.

Lovley, D. R. and Phillips, E. J. P.: Rapid assay for microbially reducible ferric iron in aquatic sediments, Appl. Environ. Microbiol., 53, 1536-1540, 1987b.

Lu, Y. H., Lueders, T., Friedrich, M. W., and Conrad, R.: Detecting active methanogenic populations on rice roots using stable isotope probing, Environ. Microbiol., 7, 326-336, 2005.

Lu, Y. and Conrad, R.: In situ stable isotope probing of methanogenic archaea in the rice rhizosphere, Science, 309, 1088-1090, 2005.

Ludwig, W., Strunk, O., Westram, R., Richter, L., Meier, H., Yadhukumar, Buchner, A., Lai, T., Steppi, S., Jobb, G., Forster, W., Brettske, I., Gerber, S., Ginhart, A. W., Gross, O., Grumann, S., Hermann, S., Jost, R., Konig, A., Liss, T., Lussmann, R., May, M., Nonhoff, B., Reichel, B., Strehlow, R., Stamatakis, A., Stuckmann, N., Vilbig, A., Lenke, M., Ludwig, T., Bode, A., and Schleifer, K. H.: ARB: a software environment for sequence data, Nucl. Acid. Res., 32, 1363-1371, 2004.

Lueders, T. and Friedrich, M. W.: Effects of amendment with ferri- hydrite and gypsum on the structure and activity of methanogenic populations in rice field soil, Appl. Environ. Microbiol., 68, 2484-2494, 2002.

Lueders, T., Pommerenke, B., and Friedrich, M. W.: Stable-isotope probing of microorganisms thriving at thermodynamic limits: syntrophic propionate oxidation in flooded soil, Appl. Environ. Microbiol., 70, 5778-5786, 2004.

Luton, P. E., Wayne, J. M., Sharp, R. J., and Riley, P. W.: The mcrA gene as an alternative to $16 \mathrm{~S}$ rRNA in the phylogenetic analysis of methanogen populations in landfill, Microbiology, 148, 35213530, 2002.

Matthews, E.: Wetlands, in: Atmospheric Methane. Its role in the global environment, edited by: Khalil, M. A. K., Springer, 202233, 2000.

Mayer, H. P. and Conrad, R.: Factors influencing the population of methanogenic bacteria and the initiation of methane production upon flooding of paddy soil, FEMS Microbiol.Ecol., 73, 103112,1990

Metje, M. and Frenzel, P.: The effect of temperature on anaerobic ethanol oxidation and methanogenesis in an acidic peat from a northern wetland, Appl. Environ. Microbiol., 71, 8191-8200, 2005.

Metje, M. and Frenzel, P.: Methanogenesis and methanogenic pathways in a peat from subarctic permafrost, Environ. Microbiol., 9, 954-964, 2007.

Miller, L. G. and Oremland, R. S.: Difluoromethane, a new and improved inhibitor of methanotrophy, Appl. Environ. Microbiol., 64, 4357-4362, 1998

Murase, J., Noll, M., and Frenzel, P.: The impact of protists on activity and structure of the bacterial community in a rice field soil, Appl. Environ. Microbiol., 72, 5436-5444, 2006.

Murayama, S. and Zahari, A. B.: Decomposition of tropical peat soils. 2. Estimation of in situ decomposition by measurement of $\mathrm{CO}_{2}$ flux, JARQ-Jpn. Agr. Res. Q., 30, 153-158, $1996 \mathrm{a}$.

Murayama, S. and Zahari, A. B.: Decomposition of tropical peat soils.1. Decomposition kinetics of organic matter of peat soils, JARQ-Jpn. Agr. Res. Q., 30, 145-151, 1996b.

Nivet, C. and Frazier, S.: A Review of European Wetland Invetory Information. Report prepared in the framework of "A Pilot Study towards a Pan-European Wetland Inventory", a cooperative project between Wetlands International and the Dutch Institute for Inland Water Management and Waste Water Treatment (RIZA), 1-262, 2004.

Ochsenreiter, T., Selezi, D., Quaiser, A., Bonch-Osmolovskaya, L., and Schleper, C.: Diversity and abundance of Crenarchaeota in terrestrial habitats studied by 16S RNA surveys and real time PCR, Environ. Microbiol., 5, 787-797, 2003.

Penning, H. and Conrad, R.: Effect of inhibition of acetoclastic methanogenesis on growth of archaeal populations in an anoxic model environment, Appl. Environ. Microbiol., 72, 178-184, 2006.

Peters, V. and Conrad, R.: Methanogenic and other strictly anaerobic bacteria in desert soil and other oxic soils, Appl. Environ. Microbiol., 61, 1673-1676, 1995.

Ponnamperuma, F. N.: The chemistry of submerged soils, Adv. Agronomy, 24, 29-96, 1972.

Ratering, S. and Schnell, S.: Localization of iron-reducing activity in paddy soil by profile studies, Biogeochemistry, 48, 341-365, 2000 . 
Rosenthal, G.: Selecting target species to evaluate the success of wet grassland restoration, Agric. Ecosyst. Environ., 98, 227-246, 2003.

Schmidt, H. A., Strimmer, K., Vingron, M., and von Haeseler, A.: TREE-PUZZLE: maximum likelihood phylogenetic analysis using quartets and parallel computing, Bioinformatics, 18, 502504, 2002.

Schulz, S. and Conrad, R.: Influence of temperature on pathways to methane production in the permanently cold profundal sediment of Lake Constance, FEMS Microbiol. Ecol., 20, 1-14, 1996.

Seliškar, A.: Water, boggy marshy and grassy vegetation on Ljubljansko barje (eastern part), Scopolia, 10, 1-41, 1986.
Šifrer, M.: New findings on the geomorphological development on the Ljubljansko barje, Acta Geographica, 23, 1-55, 1984.

Springer, E., Sachs, M. S., Woese, C. R., and Boone, D. R.: Partial gene-sequences for the A-subunit of methyl-coenzyme $\mathrm{M}$ reductase (mcrI) as a phylogenetic tool for the family Methanosarcinaceae, Int. J. Syst. Bacteriol., 45, 554-559, 1995.

Stres, B., Danevcic, T., Pal, L., Fuka, M. M., Resman, L., Leskovec, S., Hacin, J., Stopar, D., Mahne, I., and Mandic-Mulec, I.: Influence of temperature and soil water content on bacterial, archaeal and denitrifying microbial communities in drained fen grassland soil microcosms, FEMS Microbiol. Ecol., 66, 110-122, 2008. 